\title{
Adsorption of Procion Red MX-5B dye from aqueous solution using homemade peach and commercial activated carbons
}

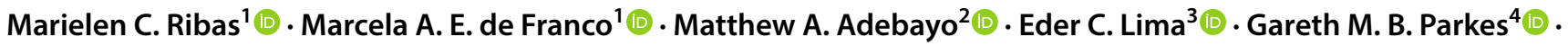 \\ Liliana A. Feris ${ }^{1}$ (D)
}

Received: 24 January 2020 / Accepted: 19 May 2020 / Published online: 3 June 2020

(c) The Author(s) 2020

\begin{abstract}
Wastewater treatment is of great concern in the textile industries because dyes, which are released into wastewater, are stable due to their structures and that some of the existing conventional techniques are not effective for aqueous removal of dyes. Among the advanced techniques for treatment of industrial effluents, adsorption is one of the most effective processes for removal of dyes from industrial wastewater. Similarly, activated carbons from different sources have been successfully applied as adsorbents for dye removal from aqueous solutions. In this context, this research evaluated the performance of activated carbon produced from peach pit (APC-1.0) for removal of a textile dye, Procion Red MX-5B (PR-5B), through batch adsorption process. The characteristic features of the peach activated carbon were obtained through Fourier transforms infrared spectroscopy, and scanning electron microscopy. The effectiveness of the activated to remove PR-5B from aqua system was compared with that of commercial activated carbon (CAC). In the kinetic study, the contact time was evaluated between 0 and 480 min using two different initial concentrations. Adsorption isotherms of PR-5B onto the two adsorbents were investigated in six different temperatures (298-326 K). The thermodynamic parameters of the process indicated spontaneous and exothermic adsorption. Equilibrium data were best described by Liu isotherm model with maximum removal capacities of 297.2 and $174.0 \mathrm{mg} \mathrm{g}^{-1}$ for APC-1.0 and CAC, respectively.
\end{abstract}

Keywords Adsorption $\cdot$ Peach seed $\cdot$ Activated carbon $\cdot$ Isotherm $\cdot$ Microwave regeneration

Marielen C. Ribas

marielencozer@yahoo.com.br

$\triangle$ Matthew A. Adebayo

adebayoma@futa.edu.ng

1 Department of Chemical Engineering, Federal University of Rio Grande do Sul (UFRGS), Rua Engenheiro Luiz Englert, Building 12204, Porto Alegre, RS 90040-040, Brazil

2 Department of Chemistry, The Federal University of Technology, Akure, Ondo State, Nigeria

3 Institute of Chemistry, Federal University of Rio Grande do Sul (UFRGS), Av. Bento Gonçalves 9500, Postal Box 15003, Porto Alegre, RS 91501-970, Brazil

4 Department of Chemical and Biological Sciences, University of Huddersfield, Queensgate, Huddersfield HD1 3DH, UK

\section{Introduction}

Effluents containing dyes, when released into rivers, can cause serious environmental problems. The presence of dyes in water is undesirable due to the lasting color and can cause a decrease in water transparency even at low concentrations, thereby preventing the penetration of sunlight and hindering the process of photosynthesis and increasing the chemical oxygen demand (Bae and Freeman 2007; Rosales et al. 2016). Furthermore, some dyes can cause allergies, cancer, and mutations (Alves de Lima et al. 2007; Demarchi et al. 2013).

The treatment of effluents containing dyes is one of the biggest challenges for the textile industry due to the fact that these substances have high chemical and structural stability, and are commonly persistent to the conventional wastewater treatments. Thus, it is usually necessary to apply more than one technology since each procedure has a limitation and the dyes are resistant to degradation and are photostable (Guaratini and Zanoni 2000). Among the existing methods for

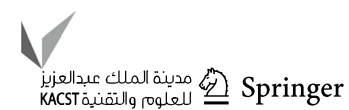


the treatment of textile effluents, the adsorption has several advantages such as high color removal efficiency, low cost, ease of operation, continuous processing of large volumes of waste, and high possibility of regenerating spent adsorbent (Carneiro et al. 2010; Sharma et al. 2013; Rovani et al. 2014).

Due to the high stability of dyes, adsorption is one of the most efficient treatment process due to the easiness of design, operational simplicity and good efficiency in the removal of several type of pollutants, including dyes (Ribas et al. 2014; Rosales et al. 2016; Bazzo et al. 2016). In recent years, activated carbons have been mentioned by the Environmental Protection Agency of the USA as the best available control technology for wastewater treatment (de Franco et al. 2017). Although, there is a growing interest in search for alternative low-cost adsorbents, especially those prepared from wastes (SenthilKumar et al. 2010; Baccar et al. 2012; Dorado et al. 2014).

Brazil has a great agricultural potential and in this scenario the production of a large volume of waste can represent an environmental issue. The use of agricultural wastes to produce adsorbents is advantageous and economic alternative, which can be further used for water and wastewater treatment (Ribas et al. 2014).

In the present study, homemade peach activated carbon (APC), a low-cost adsorbent, was prepared and applied for the removal of Procion red, a textile dye, through batch adsorption process. Batch experiments were performed to investigate kinetic, equilibrium and thermodynamic aspects of the adsorption process. The adsorption potential of APC was compared with that of commercial activated carbon (CAC).

\section{Materials and methods}

\section{Preparation of the adsorbent}

Peach pit was collected, dried in an oven at $105^{\circ} \mathrm{C}$ for $24 \mathrm{~h}$, ground in a knife mill and properly stored for later use. For comparative purposes, all adsorption experiments were also carried out using commercial activated carbon (CAC) supplied by Merck (325-400 mesh) under the same experimental conditions of the synthesized peach carbon.

\section{Carbon synthesis}

The activated carbon was prepared using the following procedure: $70 \mathrm{~g}$ of organic component (peach pit powder), $70 \mathrm{~g}$ of inorganic components $(28.6 \%$ clay, $28.6 \%$ lime, $14.3 \%$ of $\mathrm{KOH}, 14.3 \% \mathrm{Al}\left(\mathrm{NO}_{3}\right)_{3}$ and $\left.14.2 \% \mathrm{Na}_{2} \mathrm{SO}_{4}\right)$, and $50.0 \mathrm{~mL}$ of water were thoroughly mixed to obtain a homogeneous paste (Ribas et al. 2014; Saucier et al. 2015).
The resulting wet paste was placed in a cylinder of 4.8 by $14.0 \mathrm{~cm}$ and dried at room temperature for $24 \mathrm{~h}$. The cylinder together with the paste was then placed in a stainlesssteel reactor. The reactor was heated in the tubular furnace at $293 \mathrm{~K} \mathrm{~min}^{-1}$ to $1073 \mathrm{~K}$ and remained at that temperature for $30 \mathrm{~min}$. The resulting adsorbent was cooled to ambient temperature under Argon flow $\left(25 \mathrm{~mL} \mathrm{~min}^{-1}\right)$, ground, sieved to a particle size $\leq 150 \mu \mathrm{m}$, and stored in a sealed container until used.

To remove inorganic compounds and improve the adsorption capacity of the produced activated peach carbon, chemical activation was performed on the adsorbent. The procedure used is summarized as: $10 \mathrm{~g}$ of the carbon was placed in contact with $200 \mathrm{~mL}$ of $6 \mathrm{~mol} \mathrm{~L}^{-1} \mathrm{HCl}$ in a $500-\mathrm{mL}$ boiling flask, and the mixture was stirred on a magnetic stirrer for $2 \mathrm{~h}$ under reflux at $70{ }^{\circ} \mathrm{C}$. The slurry was cooled down and filtered under vacuum using $0.45 \mu \mathrm{m}$ membranes in a polycarbonate Sartorius system. The residue, after extensive washing with water ( $\mathrm{pH} 2.0$ ), was oven-dried at $100{ }^{\circ} \mathrm{C}$ for $5 \mathrm{~h}$ and stored until use. The adsorbent was named activated peach carbon (APC-1.0). The APC- 1.0 contain peach pit (precursor) and inorganic components in a ratio $1: 1$. The ratio of the precursor to inorganics was varied during preliminary experiments, however, the composition of 1:1 (precursor/inorganic) gave the highest adsorption capacity, hence was used for further studies.

\section{Characterization activated carbon}

The activated carbon from peach was characterized using Fourier transform infrared (FTIR) spectroscopy, and scanning electron microscope (SEM). The surface morphology of APC-1.0 was obtained using SEM (Hitachi, Tabletop microscope model TM3000, Tokyo, Japan). The functional groups present in APC-1.0 were visualized FTIR (Shimadzu Spectrometer, IR Prestige 21, Kyoto, Japan). For FTIR analysis, APC-1.0 and $\mathrm{KBr}$ were dried in an oven at $120^{\circ} \mathrm{C}$ for $8 \mathrm{~h}$ and kept in a desiccator. The spectrum was obtained with a resolution of $4 \mathrm{~cm}^{-1}$ with 100 cumulative scans.

\section{Preparation of the solutions}

The stock solution (5000 $\mathrm{mg} \mathrm{L}^{-1}$ ) of Procion Red MX-5B dye (CAS: 17804-49-8, $\mathrm{C}_{19} \mathrm{H}_{10} \mathrm{Cl}_{2} \mathrm{~N}_{6} \mathrm{O}_{7} \mathrm{~S}_{2}, 615.33 \mathrm{~g} \mathrm{~mol}^{-1}$, Sigma-Aldrich, purity $40 \%$, Fig. 1) was prepared by dissolving $5.0 \mathrm{~g}$ of the dye in deionized water. All working solutions used in the experiments were obtained by dilution of the stock solution. The $\mathrm{pH}$ adjustment, when needed, was performed with addition of $0.1 \mathrm{~mol} \mathrm{~L}^{-1} \mathrm{HCl}$ or $\mathrm{NaOH}$ solution. 
<smiles></smiles>

Fig. 1 Molecular structure of Procion Red MX-5B

\section{Batch studies}

Batch adsorption experiments were carried out in $50 \mathrm{ml}$ Falcon tubes with $20 \mathrm{~mL}$ of dye solution and $50 \mathrm{mg}$ of adsorbent. Samples were agitated in a thermostatic shaker at $150 \mathrm{rpm}$ at pre-determined times. The mixtures were then centrifuged for $10 \mathrm{~min}$ at $15,000 \mathrm{rpm}$. To determine the residual dye in the supernatant, the solution was analyzed by UV-VIS spectrophotometer (T90, PG Instruments, London, United Kingdom) at a wavelength of $536 \mathrm{~nm}$. When necessary, aliquots were diluted with an aqueous solution (water of suitable $\mathrm{pH}$ ) before spectroscopic measurement. The amount of adsorbed dye and the percentage removal are calculated using Eqs. 1 and 2, respectively.

$q=\frac{\left(C_{0}-C_{\mathrm{f}}\right)}{m} \cdot V$

$\%$ Removal $=\frac{\left(C_{0}-C_{\mathrm{f}}\right)}{C_{0}} \cdot 100$

where $q$ is the amount of dye adsorbed by the adsorbent in $\mathrm{mg} \mathrm{g}^{-1}, C_{0}$ is the initial dye concentration in contact with the adsorbent in $\mathrm{mg} \mathrm{L}^{-1}, C_{\mathrm{f}}$ is the final dye concentration after the adsorption process in $\mathrm{mg} \mathrm{L}^{-1}, m$ is the mass of adsorbent in $\mathrm{g}$ and $V$ is the volume of dye solution in $\mathrm{L}$.

\section{Kinect study}

For the kinetic adsorption study, the contact times were varied between 0 and $480 \mathrm{~min}$ using two different initial concentrations (400 and $600 \mathrm{mg} \mathrm{L}^{-1}$ ). These initial concentrations were selected because it is believed that in these conditions the saturation of the adsorbent material would be achieved.

The kinetic models used for evaluation and explanation of kinetic data were pseudo-first-order, pseudo-second-order, general-order and intra-particle diffusion models. The respective models are represented by Eqs. 3-6.

$\frac{\mathrm{d} q_{t}}{\mathrm{~d} t}=k_{1}\left(q_{e}-q_{t}\right)$

$\frac{\mathrm{d} q_{t}}{\mathrm{~d} t}=k_{2}\left(q_{2}-q_{t}\right)^{2}$

$q_{t}=q_{e}-\frac{q_{e}}{\left[k_{N}\left(q_{e}\right)^{n-1} \cdot t \cdot(n-1)+1\right]^{1 / 1-n}}$

$q_{t}=k_{\mathrm{id}} \cdot t^{1 / 2}$

where $k_{1}$ is the pseudo-first-order rate constant in $\min ^{-1} ; k_{2}$ is the pseudo-second-order rate constant in $\mathrm{g} \mathrm{mg}^{-1} \mathrm{~min}^{-1}$; $k_{n}$ is the $n$th order rate constant in $\min ^{-1}\left(\mathrm{~g} \mathrm{mg}^{-1}\right)^{\mathrm{n}-1} ; k_{\text {id }}$ is the intra-particle rate constant in $\mathrm{mg} \mathrm{g}^{-1} \mathrm{~min}^{-0.5}, n$ is the order of reaction; $q_{e}$ is the amount of dye adsorbed by the adsorbent at equilibrium in $\mathrm{mg} \mathrm{g}^{-1}$; and $q_{t}$ is the amount of dye adsorbed by the adsorbent at time, $t$, in $\mathrm{mg} \mathrm{g}^{-1}$.

\section{Equilibrium study}

Experiments were performed using different dye concentrations in the range $500-1700 \mathrm{mg} \mathrm{L}^{-1}$ to cover a wide range of concentrations since industrial waste disposal show varying concentrations. Studies were performed at six different temperatures, which ranged between 25 and $50{ }^{\circ} \mathrm{C}$.

The mathematical models used to describe the adsorption isotherms were Langmuir (1918), Freundlich (1906) and Liu et al. (2003) as shown in Eqs. 7-9 respectively.

$q=\frac{K \cdot Q_{\mathrm{max}} \cdot C_{\mathrm{f}}}{1+K \cdot C_{\mathrm{f}}}$

$q_{e}=K_{\mathrm{F}} \cdot C_{\mathrm{f}}^{1 / n}$

$q_{e}=\frac{Q_{\max } \cdot\left(K_{\mathrm{g}} \cdot C_{\mathrm{f}}\right)^{n_{\mathrm{L}}}}{1+\left(K_{\mathrm{g}} \cdot C_{\mathrm{f}}\right)^{n_{\mathrm{L}}}}$

Kinetic and equilibrium data were subjected to nonlinear fitting methods with successive interactions calculated by the Levenberg-Marquardt method. Interactions were also evaluated with the aids of the simplex method, based on the nonlinear fitting facilities of the Microcal Origin 9.0 software. A determination coefficient $\left(R^{2}\right)$, an adjusted determination coefficient $\left(R_{\text {adj }}^{2}\right)$ and an error function $\left(F_{\text {error }}\right)$ were jointly used to evaluate the suitability of the models used 
(Cardoso et al. 2011; Saucier et al. 2015). A $F_{\text {error }}$ is defined as a measure of the differences between the theoretical and experimental amounts of dye adsorbed. The $R^{2}, R_{\text {adj }}^{2}$ and $F_{\text {error }}$ are given by Eqs. $10-12$, respectively.

$$
\begin{aligned}
& R^{2}=\left(\frac{\sum_{i}^{n}\left(q_{i, \text { exp }}-\bar{q}_{i, \text { exp }}\right)^{2}-\sum_{i}^{n}\left(q_{i, \text { exp }}-q_{i, \text { model }}\right)^{2}}{\sum_{i}^{n}\left(q_{i, \exp }-\bar{q}_{i, \text { exp }}\right)^{2}}\right) \\
& R_{\text {adj }}^{2}=1-\left(1-R^{2}\right) \cdot\left(\frac{n-1}{n-p-1}\right) \\
& F_{\text {error }}=\sqrt{\left(\frac{1}{n-p}\right) \cdot \sum_{i}^{n}\left(q_{i, \text { exp }}-q_{i, \text { model }}\right)^{2}}
\end{aligned}
$$

In these equations, $q_{i, \text { model }}$ represents individual theoretical $q$ value predicted by the model; $q_{i, \text { exp }}$ represents individual experimental $q$ value; $\bar{q}_{\text {exp }}$ is the average of experimental $q ; n$ represents the number of experiments while $p$ represents the number of parameters in the fitting model (Cardoso et al. 2011; dos Reis et al. 2017).

\section{Thermodynamic study}

The thermodynamic parameters related to the adsorption process, standard Gibbs energy $\left(\Delta G^{\circ}, \mathrm{kJ} \mathrm{mol}^{-1}\right)$, standard enthalpy change $\left(\Delta H^{\circ}, \mathrm{kJ} \mathrm{mol}^{-1}\right)$ and entropy change $\left(\Delta S^{\circ}\right.$, $\mathrm{J} \mathrm{mol}^{-1} \mathrm{~K}^{-1}$ ), were determined using Eqs. 13-15. Equation 15 is obtained from Eqs. (13) and (14)

$\Delta G^{\circ}=\Delta H^{\circ}-T \cdot \Delta S^{\circ}$

$\Delta G^{\circ}=-R \cdot T \cdot \ln (K)$

$\ln (K)=\frac{\Delta S^{\circ}}{R}-\frac{\Delta H^{\circ}}{R} \frac{1}{T}$

where $R$ is the universal gas constant $\left(8.314 \mathrm{~J} \mathrm{~K}^{-1} \mathrm{~mol}^{-1}\right) ; T$ is the absolute temperature $(\mathrm{K}) ; K$ is the adsorption equilibrium constant at the isotherm that best described the equilibrium data. Different adsorption equilibrium constants can be obtained from different isotherm models (Calvete et al. 2010; Alencar et al. 2012; Cardoso et al. 2012; Dotto et al. 2012; Suksabye and Thiravetyan 2012). Thermodynamic parameters can also be calculated from the Liu equilibrium constant, $K_{\mathrm{g}}$, as already reported (Prola et al. 2013; Adebayo et al. 2014; Ribas et al. 2014).

\section{Microwave regeneration}

The spent adsorbent was regenerated using microwave system. The regeneration system was made up of quartz reactor loaded with pre-dried carbon, through which the gas flows. The temperature was controlled by two thermocouples. The microwave oven was operated at a frequency of $2.45 \mathrm{GHz}$ with variable power from 0 to $1000 \mathrm{~W}$ provided by a microwave generator (Sairem). Microwaves were transmitted from the generator in a waveguide made of brass (Type 340, internal dimensions of $86.943 \mathrm{~mm}$ ). This waveguide has a refrigerated cylinder with water inside, and it was used to absorb any reflected power. Temperature, heating rates, microwave power and gas flow rate were all controlled through a computer system using software developed just for this purpose (Fidalgo et al. 2014).

The heating ramp was $5 \mathrm{~K} \mathrm{~min}^{-1}$ and $\mathrm{N}_{2}$ gas was used with a flow rate of $16 \mathrm{~cm}^{3} \mathrm{~min}^{-1}$. After reaching the desired temperature, the sample remained under heating for $60 \mathrm{~min}$, and then the sample was cooled to room temperature. The carbon was regenerated.

\section{Simulation of dye-house effluents}

Two simulated dye-house effluents similar to industrial textile effluents at $\mathrm{pH} 2.0$ were used to evaluate the adsorbent removal capacity. The synthetic dye-house effluent contained five typical dyes that are commonly used as fabric colorants and auxiliary chemicals. It is known that between 10 and $60 \%$ of synthetic dyes and almost all auxiliary chemicals remain in the dye bath (Hessel et al. 2007). The representative dyes, auxiliary chemicals and their concentrations are shown in Table 1.

Table 1 Chemical composition of the simulated dye-house effluents

\begin{tabular}{lcc}
\hline & \multicolumn{2}{c}{ Concentration $\left(\mathrm{mg} \mathrm{L}^{-1}\right)$} \\
\cline { 3 - 3 } & Effluent A & Effluent B \\
\hline Dyes & 100 & 200 \\
Procion Red MX-5B & 20 & 40 \\
Reactive Violet 5 & 20 & 40 \\
Evans Blue & 20 & 40 \\
Cibracon Brilliant Yellow 3G-P & 20 & 40 \\
Reactive Red 120 & & \\
Auxiliary chemicals & 150 & 300 \\
$\mathrm{Na}_{2} \mathrm{SO}_{4}$ & 150 & 300 \\
$\mathrm{NaCl}$ & 100 & 200 \\
$\mathrm{Na}_{2} \mathrm{CO}_{3}$ & 100 & 200 \\
$\mathrm{CH}_{3} \mathrm{COONa}$ & 300 & 300 \\
$\mathrm{CH}_{3} \mathrm{OOOH}$ & 106 & 106 \\
$\mathrm{Sodium}$ & &
\end{tabular}




\section{Results and discussion}

\section{Characteristics of the activated peach carbon}

The functional groups on the APC surface was obtained using FTIR spectroscopy. As shown in Fig. 2a, the major absorption bands present and their assignments are: $3380 \mathrm{~cm}^{-1}$ (O-H stretching vibration of alcohol), $1628 \mathrm{~cm}^{-1}$ (aromatic rings), $1103 \mathrm{~cm}^{-1}$ (C-O of alcohols and $\mathrm{Si}-\mathrm{O}$ of silicates), and $789 \mathrm{~cm}^{-1}$ (C-H of aromatic out-of-plane bending). Some of these functional groups are responsible for adsorption of PR-5B dye from aqueous solution.

The SEM micrograph that shows the surface morphology of the APC-1.0 is presented in Fig. 2b. The particles of the adsorbent are aggregated. The porous and rough surface (characterized with irregular pores with different cavities) of the adsorbent is visible (Ribas et al. 2014; dos Reis et al. 2016). Chemical activation and leaching of inorganics from activated adsorbent have been found to increase the roughness, surface area and adsorption capacity of adsorbent (Ribas et al. 2014; Saucier et al. 2015; dos Reis et al. 2017).
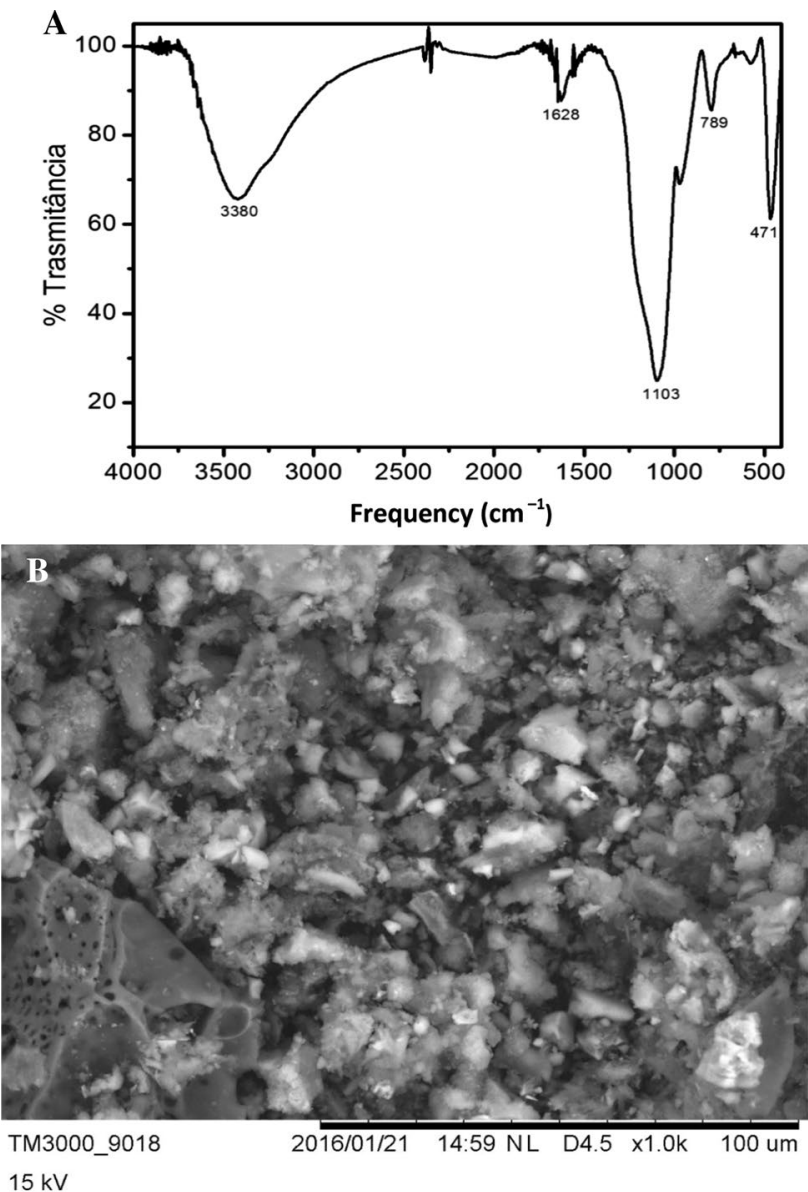

Fig. 2 The FTIR spectrum (a) and SEM micrograph (b) of APC-1.0

\section{Effect of pH}

Dyes usually have one $\mathrm{pH}$ range in which adsorption onto a certain material is favorable. The optimum $\mathrm{pH}$ value depends on the characteristics of the adsorbent and the interaction between the adsorbate and the solid surface. The $\mathrm{pH}$ effect was evaluated between 2 and 10 using $500 \mathrm{mg} \mathrm{L}^{-1}$ of Procion Red solution. The results obtained for both adsorbents, APC-1.0 and CAC, are shown in Fig. 3.

As can be seen in Fig. 3, the two adsorbents exhibit similar adsorption behavior. The APC-1.0 showed maximum percentage removal of $84.6 \%$ at $\mathrm{pH} 2$. With the increase of $\mathrm{pH}$, the percentage removal decreased until it reached its minimum value of $64.4 \%$ at $\mathrm{pH} 10$. For the commercial activated carbon (CAC), no significant variation in the percentage removal was observed between $\mathrm{pH} 2$ and 5 , with an average percentage removal of $75 \%$. However, the adsorption removal decreased with the increase of $\mathrm{pH}$ until it reached a minimum value of $61.2 \%$ at $\mathrm{pH} 10$. Adsorption capacity of cationic dyes tends to increase at relatively high $\mathrm{pH}$ values whereas for the anionic dyes, the adsorption process is favored at low $\mathrm{pH}$ (Hubbe et al. 2012). The initial $\mathrm{pH}$ of all dye working solutions was set at 2 for subsequent experiments.

\section{Kinetic studies}

The kinetic experimental data were analyzed using pseudofirst-order, pseudo-second-order, general-order, and intraparticle diffusion kinetic models. The nonlinear curves for both adsorbents are presented in Fig. 4. Table 2 shows the parameters obtained for the kinetic models using APC-1.0 and $\mathrm{CAC}$ in two different initial concentrations. As can be

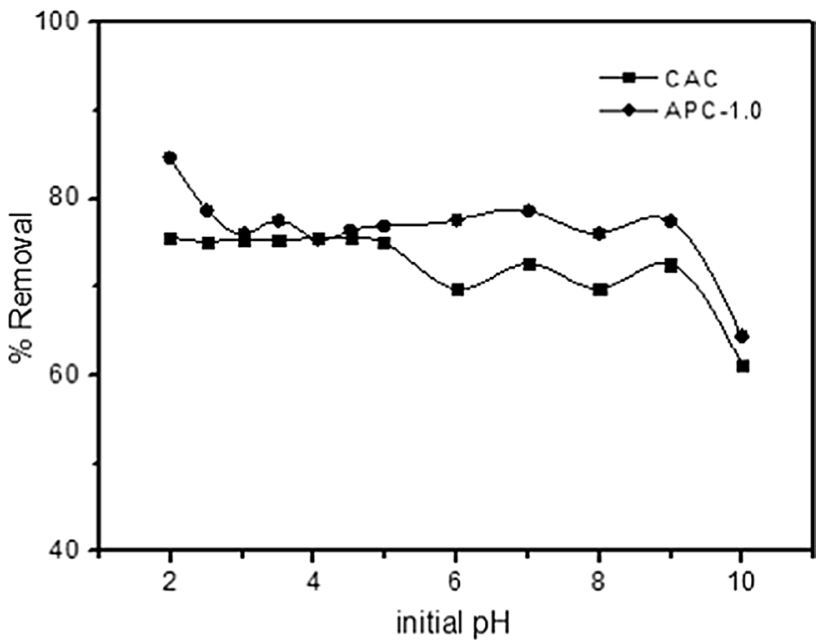

Fig. 3 Dependence of $\mathrm{pH}$ on the adsorption capacity of PR-5B dye on CAC and APC-1.0. Conditions: temperature, $298 \mathrm{~K}$; adsorbent mass, $50.0 \mathrm{mg}$; time, $8 \mathrm{~h}$; $\mathrm{pH}, 2-10$; dye concentration, $500 \mathrm{mg} \mathrm{L}^{-1}$ 

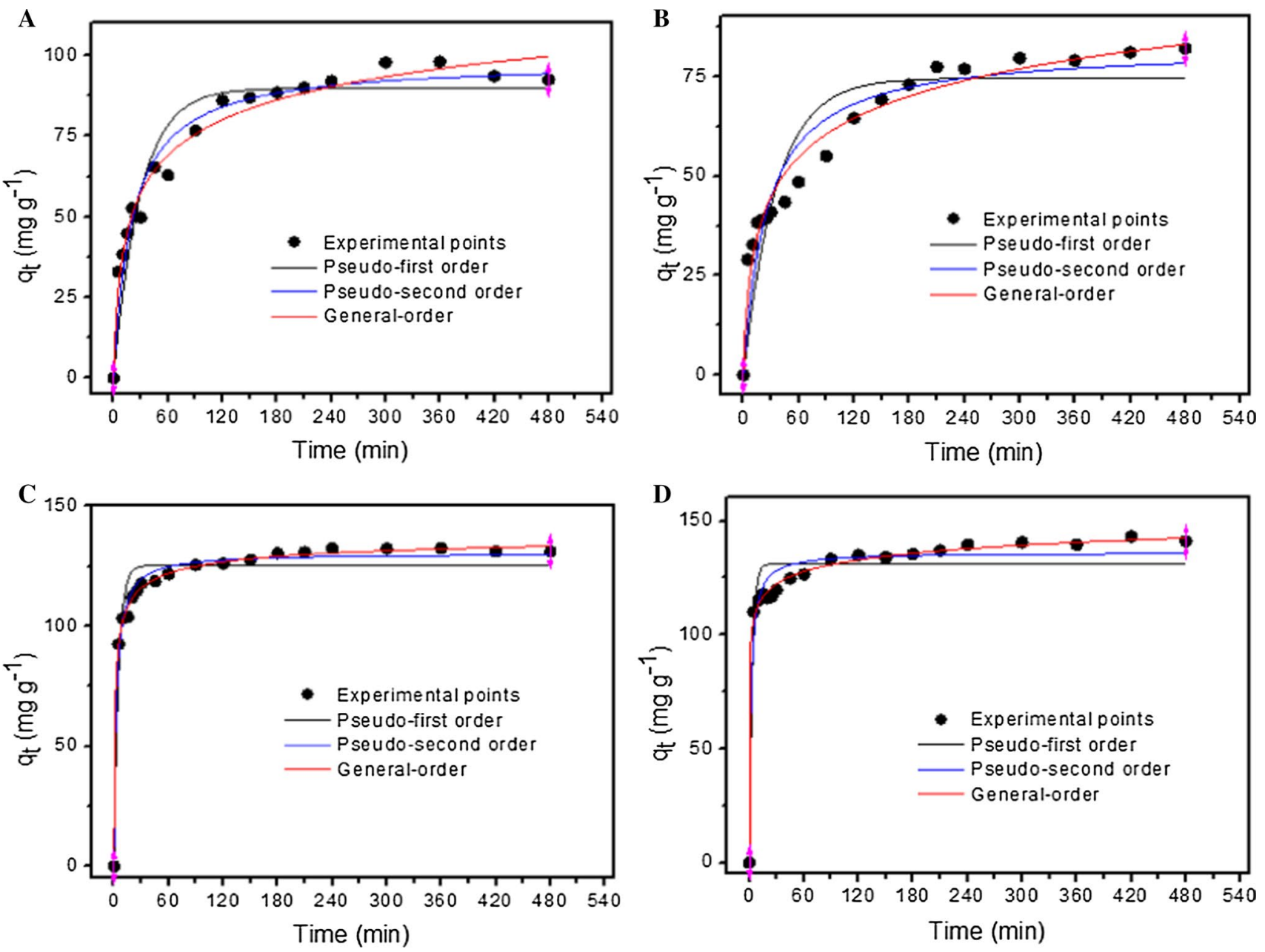

Fig. 4 Kinetic isotherm curves of a CAC and PR-5B dye at $400 \mathrm{mg}$ $\mathrm{L}^{-1}$; b CAC and PR-5B dye at $600 \mathrm{mg} \mathrm{L}^{-1}$; c APC-1.0 and PR-5B at $400 \mathrm{mg} \mathrm{L}^{-1}$; and $\mathrm{d}$ APC-1.0 and PR-5B at $600 \mathrm{mg} \mathrm{L}^{-1}$. Conditions:

observed in Fig. 4 and Table 2, experimental data were best fitted by the general-order kinetic model. Compared to other kinetic models, the general-order model showed the highest values of $R_{\text {adj }}^{2}$ for both APC-1.0 and CAC.

To choose a particular model that best-described adsorption process, $R_{\text {adj }}^{2}$ values alone are not enough for judgement. It is therefore important to consider standard deviation $\left(F_{\text {error }}\right)$ because this parameter evaluates the difference between each data point measured experimentally and theoretical data point predicted by model (Alencar et al. 2012; Adebayo et al. 2014). Hence, $F_{\text {error }}$ values were analyzed. For the pseudo-first-order model $F_{\text {error }}$ ranged from 5.99 to 8.25 for APC-1.0 and from 6.22 and 6.52 for CAC. For the pseudo-second-order model, $F_{\text {error }}$ ranged from 2.39 to 5.16 and 4.16 to 3.55 for APC-1.0 and CAC, respectively. For the general-order kinetic model, $F_{\text {error }}$ ranged between 1.14 and 1.83 for APC-1.0 and from 3.55 to 4.16 for CAC. The observation indicates that the general-order model best initial $\mathrm{pH}, 2$; temperature, $25^{\circ} \mathrm{C}$; adsorbent mass, $50 \mathrm{mg}$; and contact times, $0-480 \mathrm{~min}$

explained the adsorption process of the PR-5B dye onto both activated carbons.

It is pertinent to discuss some of the parameters of general-order model, which is the best kinetic model in this study. The values of rate constant, $k_{n}$, decreased for the two adsorbents when the concentration of the dye was increased. The reaction was faster when few molecules of the dye was present in the solution, as the number of molecules (concentration) increased to compete for relatively the same number of active sites, the reaction rate decreased. However, the initial rate constant, $h_{o}$, increased when the concentration was increased. In another way, when the initial concentration was increased by 1.5 -fold, the half-lives (the times require to attain $50 \%$ of $q_{e}$ ) of adsorption process increased by ca. 3.9-fold and 1.4-fold for APC-1.0 and CAC, respectively. That is, the time to reach $50 \%$ of equilibrium amount increased with concentration. This observation is expected because there 
Table 2 Kinetic parameters PR-5B dye adsorption onto APC-1.0 and CAC

\begin{tabular}{|c|c|c|c|c|}
\hline & \multicolumn{2}{|l|}{ APC-1.0 } & \multicolumn{2}{|l|}{ CAC } \\
\hline & $400 \mathrm{mg} \mathrm{L}^{-1}$ & $600 \mathrm{mg} \mathrm{L}^{-1}$ & $400 \mathrm{mg} \mathrm{L}^{-1}$ & $600 \mathrm{mg} \mathrm{L}^{-1}$ \\
\hline \multicolumn{5}{|l|}{ Pseudo-first-order } \\
\hline$k_{1}\left(\min ^{-1}\right)$ & 0.2009 & 0.3115 & 0.0345 & 0.0282 \\
\hline$q_{e}\left(\mathrm{mg} \mathrm{g}^{-1}\right)$ & 125.3 & 131.1 & 89.9 & 74.6 \\
\hline$h_{0}\left(\min ^{-1}\right)$ & 25.2 & 40.8 & 3.1 & 2.1 \\
\hline$t_{1 / 2}(\min )$ & 3.4 & 2.2 & 20.0 & 24.6 \\
\hline$R_{\text {adj }}^{2}$ & 0.9329 & 0.9138 & 0.9034 & 0.8376 \\
\hline$F_{\text {error }}\left(\mathrm{mg} \mathrm{g}^{-1}\right)$ & 5.99 & 8.25 & 6.22 & 6.52 \\
\hline \multicolumn{5}{|l|}{ Pseudo-second-order } \\
\hline$k_{2}\left(\mathrm{~g} \mathrm{mg}^{-1} \min ^{-1}\right)$ & $2.87 \times 10^{-3}$ & $3.92 \times 10^{-3}$ & $4.99 \times 10^{-4}$ & $4.83 \times 10^{-4}$ \\
\hline$q_{e}\left(\mathrm{mg} \mathrm{g}^{-1}\right)$ & 130.4 & 136.1 & 98.38 & 82.38 \\
\hline$h_{0}\left(\mathrm{mg} \mathrm{g}^{-1} \min ^{-1}\right)$ & 48.81 & 72.61 & 4.830 & 3.278 \\
\hline$t_{1 / 2}(\min )$ & 2.723 & 1.752 & 20.42 & 25.21 \\
\hline$R_{\text {adj }}^{2}$ & 0.9870 & 0.9651 & 0.9578 & 0.9172 \\
\hline$F_{\text {error }}\left(\mathrm{mg} \mathrm{g}^{-1}\right)$ & 2.39 & 5.16 & 4.24 & 4.64 \\
\hline \multicolumn{5}{|l|}{ General-order } \\
\hline$k_{n}\left(\min ^{-1}\left(\mathrm{~g} \mathrm{mg}^{-1}\right)^{\mathrm{n}-1}\right)$ & $1.49 \times 10^{-6}$ & $8.83 \times 10^{-31}$ & $1.74 \times 10^{-19}$ & $1.24 \times 10^{-29}$ \\
\hline$q_{e}\left(\mathrm{mg} \mathrm{g}^{-1}\right)$ & 143.3 & 230.1 & 199.01 & 226.06 \\
\hline$n$ & 3.723 & 14.50 & 8.610 & 12.66 \\
\hline$h_{0}\left(\mathrm{mg} \mathrm{g}^{-1} \min ^{-1}\right)$ & 108.7 & 153.2 & 10.81 & 6.375 \\
\hline$t_{1 / 2}(\min )$ & 1.883 & 7.384 & 19.65 & 27.86 \\
\hline$R_{\mathrm{adj}}^{2}$ & 0.9972 & 0.9957 & 0.9740 & 0.9657 \\
\hline$F_{\text {error }}\left(\mathrm{mg} \mathrm{g}^{-1}\right)$ & 1.14 & 1.83 & 4.16 & 3.55 \\
\hline \multicolumn{5}{|l|}{ Intra-particle diffusion } \\
\hline$k_{\mathrm{id}, 2}\left(\mathrm{mg} \mathrm{g}^{-1} \min ^{-0.5}\right)^{*}$ & 4.219 & 2.908 & 2.473 & 4.164 \\
\hline
\end{tabular}

Conditions: initial $\mathrm{pH}, 2$; temperature, $25^{\circ} \mathrm{C}$; adsorbent mass, $50 \mathrm{mg}$; and contact times, 0-480 min *Second stage

are more molecules of the dye at $600 \mathrm{mg} \mathrm{L}^{-1}$ than at $400 \mathrm{mg} \mathrm{L}^{-1}$, hence more time is needed for the process to be half-completed at $600 \mathrm{mg} \mathrm{L}^{-1}$ than at $400 \mathrm{mg} \mathrm{L}^{-1}$.

The results from the kinetic study and the effect of $\mathrm{pH}$ indicated that the PR-5B adsorption mechanism onto APC1.0 and CAC involves ion exchange mechanisms. To confirm the existence of electrostatic attractions, thermodynamic study was conducted.

To determinate the influence of mass transfer resistance in the PR-5B adsorption on the two adsorbents, the intraparticle diffusion model was used. The graph of $q_{t}$ versus $t^{1 / 2}$ is shown in Fig. 5. The adsorption of PR-5B showed three steps, which are represented by three linear portions of the curve. The first linear portion is the fastest step and it is related to the transport of dye molecules to the adsorbent surface. The second portion is a slow process and it is attributed to intra-particle diffusion. The third and final step represents the stage when the diffusion through the smaller pores decreases and the equilibrium is reached (Calvete et al. 2010; de Franco et al. 2017). This kinetic profile in three well-defined linear portions reveals that adsorption is controlled by the resistance mass transfer.
According to the data presented, the minimum contact times for equilibrium to occur between the dye and the adsorbent are $120 \mathrm{~min}$ for APC-1.0 and $300 \mathrm{~min}$ for CAC. In the equilibrium experiments, the contact time was increased to ensure that equilibrium is reached even at high concentrations of the dye (Prola et al. 2013; Ribas et al. 2014).

\section{Adsorption isotherms}

Six temperatures in the range between 25 and $50{ }^{\circ} \mathrm{C}$ were studied and the equilibrium experimental data were fitted into Langmuir, Freundlich and Liu isotherms (Table 3). Isotherms at $25{ }^{\circ} \mathrm{C}$ for the PR-5B adsorption onto APC-1.0 and CAC are shown in Fig. 6. As seen in Table 3, for all temperatures evaluated, the adsorption equilibrium of PR-5B dye was best described by Liu model because the model exhibited lowest standard deviation indices among the three models. The $F_{\text {error }}$ values of Liu model ranged from 2.75 to 6.55 for APC-1.0 and from 2.34 to 4.88 for CAC. The maximum adsorption capacities $\left(Q_{\max }\right)$ of PR-5B were obtained at $25^{\circ} \mathrm{C}$ for both adsorbents tested-297.2 $\mathrm{mg} \mathrm{g}^{-1}$ for APC1.0 and $174 \mathrm{mg} \mathrm{g}^{-1}$ for CAC. This result revealed that the 

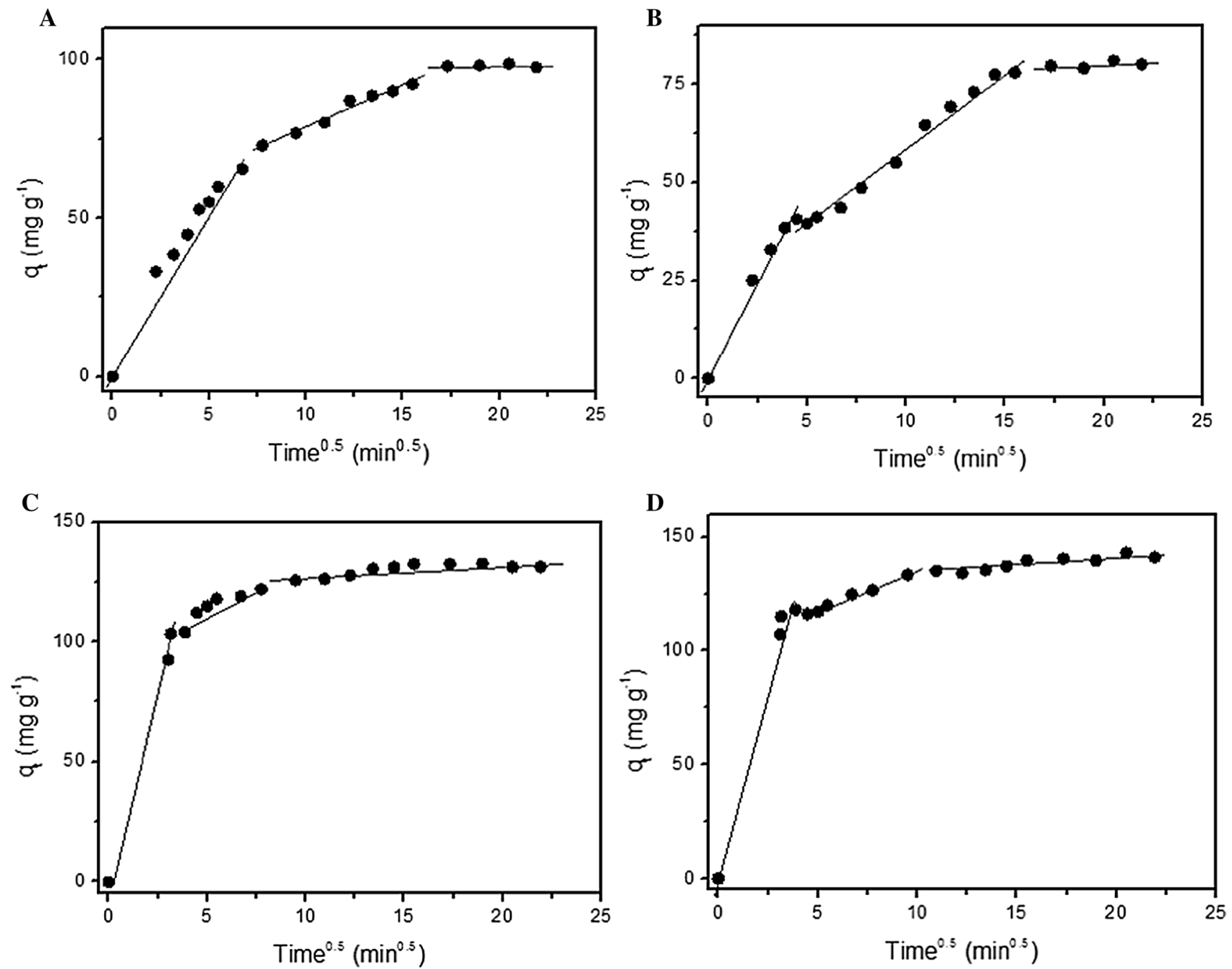

Fig. 5 Kinetic curves of intra-particle diffusion model: a $400 \mathrm{mg} \mathrm{L} \mathrm{L}^{-1}$ of PR-5B and CAC as adsorbent; b $600 \mathrm{mg} \mathrm{L}^{-1}$ of PR-5B and CAC as adsorbent; c $400 \mathrm{mg} \mathrm{L}^{-1}$ of PR-5B and APC-1.0 as adsorbent; and d $600 \mathrm{mg} \mathrm{L}^{-1}$ of PR-5B and APC-1.0 as adsorbent

activated peach carbon had higher adsorption capacity that the commercial activated carbon under the same experimental conditions.

The best model (Liu model) for description of equilibrium data in this study, combined Langmuir and Freundlich isotherm models, however, the infinite adsorption assumption from the Freundlich model and the monolayer assumption of Langmuir model were jettisoned (Liu et al. 2003). The adsorbate molecules may prefer and occupy certain active sites on the surface of adsorbent (Liu et al. 2003; Lima et al. 2015). As shown in Table 3, the Liu equilibrium constant, $K_{\mathrm{g}}\left(\mathrm{L} \mathrm{mg}^{-1}\right)$, decreases as temperature increases. This signifies that an increase in temperature does not favor the adsorption process, hence, an exothermic process. The values $n_{\mathrm{L}}$ (dimensionless exponent of the Liu model) assume positive values and range from 0.8516 to 3.262 for APC-1.0 from 0.9659 to 4.055 for CAC.

\section{Thermodynamic study}

The results of thermodynamic study obtained for PR-5B adsorption onto APC-1.0 and CAC are shown in Table 4. According to Table 4 , the negative values of $\Delta G^{\circ}$ reveal that the adsorption onto both adsorbents occurred spontaneously. The negative values of $\Delta H^{\circ}$ indicate the process was exothermic and that the adsorption process exhibited physical characteristics (physisorption) (Sun and Wang 2010; Rathod et al. 2015). Negative values of $\Delta S^{\circ}$ indicate that with an increase in temperature, there is a reduction in system instability at the solid/fluid interface, i.e., the dye molecules exhibit more ordered layers on the surface of the adsorbent (Gupta et al. 2011). 
Table 3 Isotherm parameters for PR-5B dye adsorption using APC-1.0 and CAC

\begin{tabular}{|c|c|c|c|c|c|c|}
\hline & \multicolumn{6}{|c|}{ Temperature } \\
\hline & $298 \mathrm{~K}$ & $303 \mathrm{~K}$ & $308 \mathrm{~K}$ & $313 \mathrm{~K}$ & $318 \mathrm{~K}$ & $323 \mathrm{~K}$ \\
\hline \multicolumn{7}{|l|}{$A P C-1.0$} \\
\hline \multicolumn{7}{|l|}{ Langmuir } \\
\hline$Q_{\max }\left(\mathrm{mg} \mathrm{g}^{-1}\right)$ & 272.7 & 155.7 & 152.6 & 163.0 & 182.6 & 231.9 \\
\hline$K_{\mathrm{L}}\left(\mathrm{L} \mathrm{mg}^{-1}\right)$ & 0.0153 & 0.0239 & 0.0310 & 0.0254 & 0.0157 & 0.0110 \\
\hline$R_{\mathrm{adj}}^{2}$ & 0.9922 & 0.9774 & 0.9809 & 0.9616 & 0.9781 & 0.9862 \\
\hline$F_{\text {error }}\left(\mathrm{mg} \mathrm{g}^{-1}\right)$ & 8.23 & 5.64 & 4.97 & 7.37 & 4.49 & 5.67 \\
\hline \multicolumn{7}{|l|}{ Freundlich } \\
\hline$K_{\mathrm{F}}\left(\mathrm{mg} \mathrm{g}^{-1}\left(\mathrm{mg} \mathrm{L}^{-1}\right)^{-1 / \mathrm{nF}}\right)$ & 84.69 & 83.63 & 86.46 & 77.20 & 71.34 & 48.03 \\
\hline$n_{\mathrm{F}}$ & 6.054 & 11.72 & 12.57 & 9.528 & 7.774 & 4.485 \\
\hline$R_{\text {adj }}^{2}$ & 0.9697 & 0.9736 & 0.9796 & 0.9471 & 0.9507 & 0.9791 \\
\hline$F_{\text {error }}\left(\mathrm{mg} \mathrm{g}^{-1}\right)$ & 4.33 & 5.75 & 4.79 & 7.90 & 5.74 & 5.31 \\
\hline \multicolumn{7}{|l|}{ Liu } \\
\hline$Q_{\max }\left(\mathrm{mg} \mathrm{g}^{-1}\right)$ & 297.2 & 188.1 & 179.29 & 172.7 & 166.3 & 243.9 \\
\hline$K_{\mathrm{g}}\left(\mathrm{L} \mathrm{mg}^{-1}\right)$ & 0.0258 & 0.0209 & 0.0175 & 0.0142 & 0.0117 & 0.0098 \\
\hline$n_{\mathrm{L}}$ & 1.643 & 2.283 & 1.553 & 3.262 & 3.153 & 0.8516 \\
\hline$R_{\mathrm{adj}}^{2}$ & 0.9972 & 0.9772 & 0.9794 & 0.9732 & 0.9945 & 0.9854 \\
\hline$F_{\text {error }}\left(\mathrm{mg} \mathrm{g}^{-1}\right)$ & 2.75 & 5.59 & 4.34 & 6.55 & 3.21 & 5.11 \\
\hline \multicolumn{7}{|l|}{$C A C$} \\
\hline \multicolumn{7}{|l|}{ Langmuir } \\
\hline$Q_{\max }\left(\mathrm{mg} \mathrm{g}^{-1}\right)$ & 201.8 & 163.1 & 248.7 & 194.1 & 221.3 & 234.7 \\
\hline$K_{\mathrm{L}}\left(\mathrm{L} \mathrm{mg}^{-1}\right)$ & 0.0146 & 0.0335 & 0.0089 & 0.0241 & 0.0193 & 0.0115 \\
\hline$R_{\mathrm{adj}}^{2}$ & 0.9853 & 0.98 & 0.9881 & 0.9749 & 0.9923 & 0.9748 \\
\hline$F_{\text {error }}\left(\mathrm{mg} \mathrm{g}^{-1}\right)$ & 4.21 & 4.14 & 5.98 & 6.35 & 3.80 & 6.68 \\
\hline \multicolumn{7}{|l|}{ Freundlich } \\
\hline$K_{\mathrm{F}}\left(\mathrm{mg} \mathrm{g}^{-1}\left(\mathrm{mg} \mathrm{L}^{-1}\right)^{-1 / \mathrm{nF}}\right)$ & 73.35 & 109.5 & 45.80 & 88.54 & 87.65 & 55.44 \\
\hline$n_{\mathrm{F}}$ & 7.197 & 18.82 & 4.208 & 9.038 & 7.652 & 4.929 \\
\hline$R_{\mathrm{adj}}^{2}$ & 0.9701 & 0.9698 & 0.9812 & 0.9492 & 0.9788 & 0.9410 \\
\hline$F_{\text {error }}\left(\mathrm{mg} \mathrm{g}^{-1}\right)$ & 5.77 & 4.71 & 6.66 & 8.17 & 5.67 & 9.33 \\
\hline \multicolumn{7}{|l|}{ Liu } \\
\hline$Q_{\max }\left(\mathrm{mg} \mathrm{g}^{-1}\right)$ & 174.0 & 156.3 & 153.4 & 142.2 & 106.9 & 146.8 \\
\hline$K_{\mathrm{g}}\left(\mathrm{L} \mathrm{mg}^{-1}\right)$ & 0.0184 & 0.0146 & 0.0119 & 0.0096 & 0.0072 & 0.0054 \\
\hline$n_{\mathrm{L}}$ & 2.775 & 4.055 & 0.9659 & 2.234 & 1.916 & 2.174 \\
\hline$R_{\text {adj }}^{2}$ & 0.9946 & 0.9932 & 0.9871 & 0.9866 & 0.9964 & 0.9915 \\
\hline$F_{\text {error }}\left(\mathrm{mg} \mathrm{g}^{-1}\right)$ & 3.24 & 2.34 & 5.62 & 4.73 & 3.15 & 4.88 \\
\hline
\end{tabular}

Conditions: initial pH, 2; adsorbent mass, $50.0 \mathrm{mg}$; initial PR-5B concentrations $500-1700 \mathrm{mg} \mathrm{L}^{-1}$

\section{Microwave regeneration}

Regeneration experiments were performed on APC-1.0 in a series of adsorption-regeneration cycles and their results are shown in Table 5. The adsorption efficiency of PR-5B gradually decreased at every regeneration cycle. In each cycle, there was a loss of ca. $12 \%$ in the adsorbent mass. Thus, a decrease in regeneration efficiency occurred due to incomplete dye removal from the solid phase and reactions on the surface of the adsorbent which can reduce the number and size of the pores or even damages on the carbon structure (Guo et al. 2011; Salame and Bandosz 1999).
However, in all the adsorption-regeneration cycles, the efficiencies were significant. After the first cycle, $\approx 84 \%$ of removal was obtained and after the 4 th cycle the efficiency was still significant, about $40 \%$. The results showed the microwave technique used for regeneration of the saturated adsorbent, with PR-5B, is a viable method. Microwave technique was successfully used to regenerate bamboo charcoal (Liao et al. 2013). Sun et al. (2017) also studied microwave regeneration of activated carbon and obtained high percentages of recoveries after 5 cycles with a weight loss close to $20 \%$. The authors cited that the regeneration can be enhanced with the use of ultraviolet radiation. 

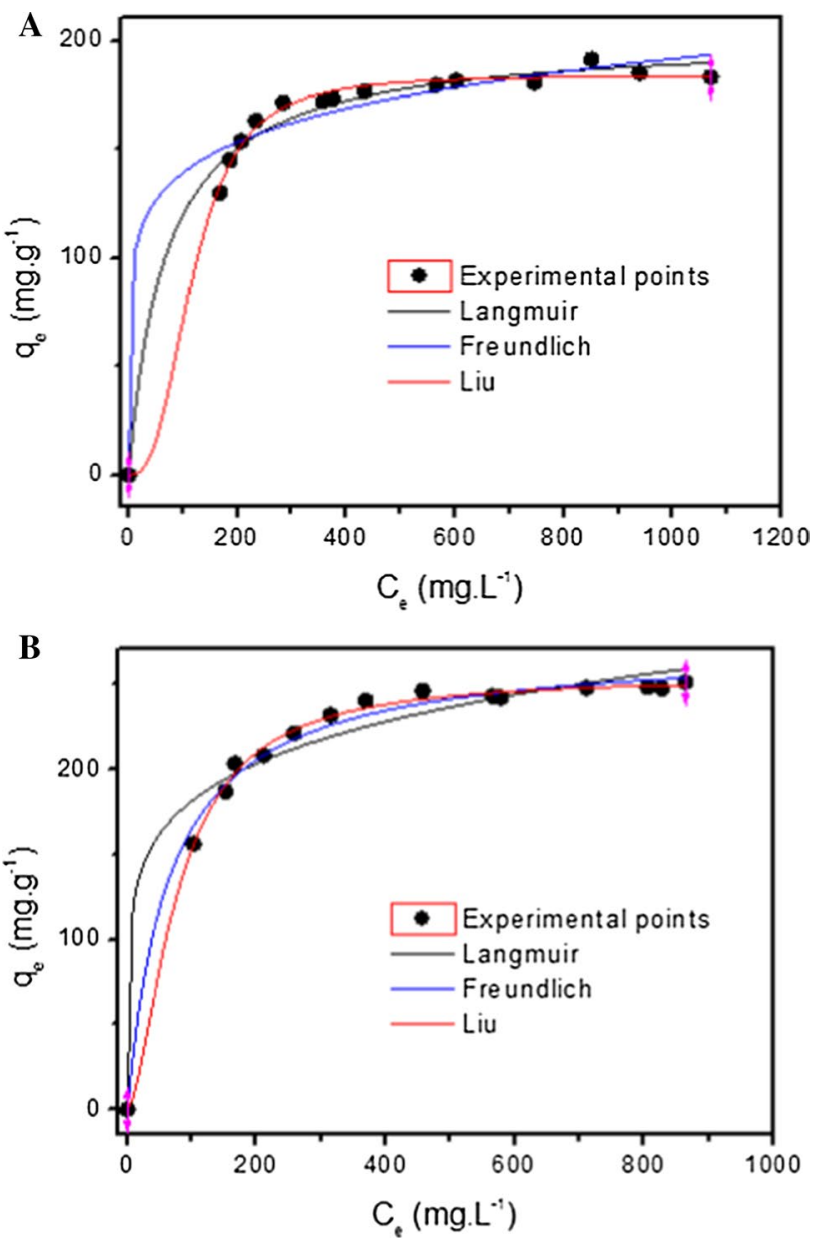

Fig. 6 Isotherm curves of adsorption of PR-5B onto a CAC and b APC- 1.0 at $25{ }^{\circ} \mathrm{C}$. Conditions: initial pH, 2; adsorbent mass, $50.0 \mathrm{mg}$; initial PR-5B concentrations 500-1700 $\mathrm{mg} \mathrm{L}^{-1}$
Table 5 Regeneration of the adsorbent for each adsorptiondesorption cycle

\begin{tabular}{ll}
\hline Cycle & $q_{e} / q_{0}(\%)$ \\
\hline 1 & $83.94 \pm 5.18$ \\
2 & $59.63 \pm 2.77$ \\
3 & $47.21 \pm 4.12$ \\
4 & $40.74 \pm 3.87$ \\
\hline
\end{tabular}

\section{Dye-house effluents}

Adsorption efficiencies of activated carbon produced from peach pit (APC-1.0) and commercial activated carbon (CAC) for the removal of PR-5B were determined using synthetic effluent solutions shown in Table 1. The UV-Vis spectra of the solutions were analyzed at wavelengths between 300 and $750 \mathrm{~nm}$. The absorbance bands used to quantitate the color removal efficiency of the effluents are shown in Fig. 7. The APC-1.0 adsorbent removed $94.7 \%$ of the compounds present in the effluent $A$ and $88.4 \%$ of the effluent $B$ while CAC removed $82.3 \%$ and $51.4 \%$ of the effluent $\mathrm{A}$ and $\mathrm{B}$, respectively. Both adsorbents were efficient and achieved high removal percentages of the textile dye. However, for the treatment of effluent $\mathrm{B}$ (effluent with high concentrations of dyes and auxiliary chemicals), APC-1.0 performed significantly better than CAC. When compared with other adsorbents reported in literature, the APC-1.0 shows high effectiveness for industrial wastewater treatment (Adebayo et al. 2014; Cardoso et al. 2012; Prola et al. 2013).

\section{Comparison of adsorption capacities of different adsorbents}

It is difficult to compare the adsorption capacities of different adsorbents for removal of a dye because dye of the same chemical structure can have different commercial names

Table 4 Thermodynamic parameters of PR-5B dye adsorption onto APC-1.0 and CAC

\begin{tabular}{|c|c|c|c|c|c|c|}
\hline & \multicolumn{6}{|l|}{ Temperature } \\
\hline & $298 \mathrm{~K}$ & $303 \mathrm{~K}$ & $308 \mathrm{~K}$ & $313 \mathrm{~K}$ & $318 \mathrm{~K}$ & $323 \mathrm{~K}$ \\
\hline \multicolumn{7}{|l|}{ APC-1.0 } \\
\hline$K_{\mathrm{g}}\left(\mathrm{L} \mathrm{mol}^{-1}\right)$ & $1.588 \times 10^{4}$ & $1.286 \times 10^{4}$ & $1.0768 \times 10^{4}$ & $8.738 \times 10^{3}$ & $7.199 \times 10^{3}$ & $6.03 \times 10^{3}$ \\
\hline$\Delta G^{\circ}\left(\mathrm{kJ} \mathrm{mol}^{-1}\right)$ & -23.96 & -23.84 & -23.77 & -23.62 & -23.48 & -23.37 \\
\hline$\Delta H^{\circ}\left(\mathrm{kJ} \mathrm{mol}^{-1}\right)$ & -31.07 & & & & & \\
\hline$\Delta S^{\circ}\left(\mathrm{J} \mathrm{K}^{-1} \mathrm{~mol}^{-1}\right)$ & -23.82 & & & & & \\
\hline$R_{\mathrm{adj}}^{2}$ & 0.9995 & & & & & \\
\hline \multicolumn{7}{|l|}{ CAC } \\
\hline$K_{\mathrm{g}}\left(\mathrm{L} \mathrm{mol}^{-1}\right)$ & $1.1322 \times 10^{4}$ & $8.983 \times 10^{3}$ & $7.322 \times 10^{3}$ & $5.907 \times 10^{3}$ & $4.443 \times 10^{3}$ & $3.323 \times 10^{3}$ \\
\hline$\Delta G^{\circ}\left(\mathrm{kJ} \mathrm{mol}^{-1}\right)$ & -23.13 & -22.93 & -22.79 & -22.60 & -22.20 & -21.77 \\
\hline$\Delta H^{\circ}\left(\mathrm{kJ} \mathrm{mol}^{-1}\right)$ & -38.67 & & & & & \\
\hline$\Delta S^{\circ}\left(\mathrm{J} \mathrm{K}^{-1} \mathrm{~mol}^{-1}\right)$ & -51.85 & & & & & \\
\hline$R_{\text {adj }}^{2}$ & 0.9911 & & & & & \\
\hline
\end{tabular}

Conditions: mass of adsorbent, $50 \mathrm{mg}$; pH, 2; temperature, 298-323 K 

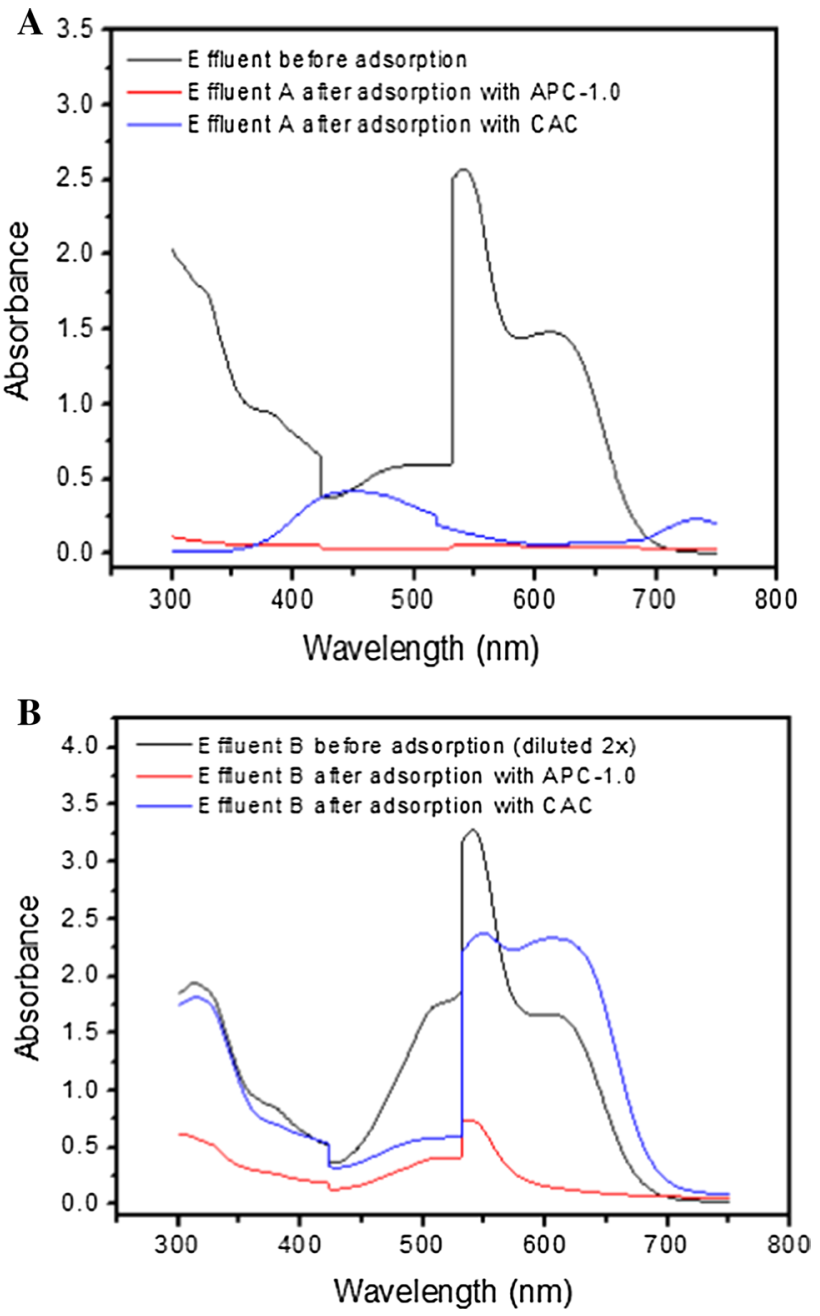

Fig. 7 UV/Visible spectra of simulated dye effluents before and after treatment with APC-1.0 and CAC. a Effluent A; and b effluent B depending on the manufacturers. However, Table 6 presents maximum adsorption capacities of different adsorbents from various studies at optimized conditions. Regarding the differences in the experimental conditions of the cited references, the activated peach carbon showed excellent adsorption capacity. It is observed that APC-1.0 had higher $Q_{\max }$ than CAC. Thus, the activated carbon reported in this work can be successfully used for the treatment of dye effluents.

\section{Conclusions}

Activated peach carbon (APC-1.0) was prepared from peach pit and its adsorption efficiency was tested for removal of a textile dye, Procion red $\mathrm{MX}-5 \mathrm{~B}$. Batch experiments were performed to investigate the kinetic, equilibrium and thermodynamic aspects of the study, and the results were compared with those of commercial activated carbon (CAC) using the same experimental conditions. The contact times for adsorption of PR-5B dye to reach equilibrium were 120 and $300 \mathrm{~min}$ for APC-1.0 and CAC, respectively, at $\mathrm{pH}$ 2. The adsorption process was best described by the general-order kinetic model. The intra-particle diffusion model was used to investigate the stages of adsorption, and the kinetic data showed that adsorption onto the two adsorbents exhibited three stages. In the investigation of isotherms, Liu model was the best model for description of equilibrium data at six different temperatures ranging from 25 to $50{ }^{\circ} \mathrm{C}$. The maximum adsorption uptake was obtained at $25{ }^{\circ} \mathrm{C}-297.2 \mathrm{mg} \mathrm{g}^{-1}$ for APC-1.0 and $174 \mathrm{mg} \mathrm{g}^{-1}$ for CAC. Thermodynamic adsorption parameters revealed that the adsorption process was exothermic $\left(\Delta H^{\circ}<0\right)$, and spontaneous $\left(\Delta G^{\circ}<0\right)$ for both adsorbents. The negative values of $\Delta S^{\circ}$ indicated that an increase in temperature reduced the system disorder.
Table 6 Maximum adsorption capacities of different adsorbents used for removal of various dyes

\begin{tabular}{llll}
\hline Adsorbent & Dye adsorbate & $Q_{\max }\left(\mathrm{mg} \mathrm{g}^{-1}\right)$ & References \\
\hline Carboxy-methyl Lignin-Al & Reactive blue MX-R & 335.7 & Adebayo et al. (2014) \\
Thamnidium elegans & Reactive red 198 & 234.2 & Akar et al. (2013) \\
SAH & Acid yellow 36 & 200.0 & Patel and Patel (2013) \\
SAH & Acid red 73 & 198.1 & Patel and Patel (2013) \\
Peanut husk treated with HCl & Drimarine black CL-B & 51.0 & Noreen et al. (2013) \\
Commercial activated carbon & Reactive red 120 & 267.2 & Cardoso et al. (2012) \\
Cupuassu shell & Reactive red 194 & 64.1 & Cardoso et al. (2011) \\
Cupuassu shell & Direct blue 53 & 37.5 & Cardoso et al. (2011) \\
Papaya stem & Methylene blue & 261.0 & Krishni et al. (2014b) \\
Banana leaves & Methylene blue & 109.9 & Krishni et al. (2014a) \\
Commercial activated carbon & Reactive violet 5 & 517.1 & Ribas et al. (2014) \\
Acidified cocoa shell activated carbon & Reactive violet 5 & 603.3 & Ribas et al. (2014) \\
Commercial activated carbon (CAC) & Procion red MX-5B & 174.0 & This work \\
Activated peach carbon (APC-1.0) & Procion red MX-5B & 297.2 & This work \\
\hline
\end{tabular}


Microwave regeneration tests with APC-1.0 were successfully conducted. After four adsorption-regeneration cycles, the adsorbent exhibited satisfactory adsorption capacities. The APC-1.0 effectively removed over $88 \%$ of textile dyes from synthetic dye-house effluents while CAC removed ca. $82 \%$.

Acknowledgements The authors are grateful to The National Council for Scientific and Technological Development (CNPq, Brazil), The Coordination of Improvement of Higher Education Personnel (CAPES, Brazil) and The Academy of Sciences for Developing World (TWAS, Italy) for financial support and fellowships.

\section{Compliance with ethical standards}

Conflict of interest All authors declare no conflict of interest in the publication of this paper.

Open Access This article is licensed under a Creative Commons Attribution 4.0 International License, which permits use, sharing, adaptation, distribution and reproduction in any medium or format, as long as you give appropriate credit to the original author(s) and the source, provide a link to the Creative Commons licence, and indicate if changes were made. The images or other third party material in this article are included in the article's Creative Commons licence, unless indicated otherwise in a credit line to the material. If material is not included in the article's Creative Commons licence and your intended use is not permitted by statutory regulation or exceeds the permitted use, you will need to obtain permission directly from the copyright holder. To view a copy of this licence, visit http://creativecommons.org/licenses/by/4.0/.

\section{References}

Adebayo MA, Prola LDT, Lima EC, Puchana-Rosero MJ, Cataluña R, Saucier C, Umpierres CS, Vaghetti JCP, da Silva LG, Ruggiero R (2014) Adsorption of Procion Blue MX-R dye from aqueous solutions by lignin chemically modified with aluminium and manganese. J Hazard Mater 268:43-50. https://doi.org/10.1016/j. jhazmat.2014.01.005

Akar T, Arslan S, Akar ST (2013) Utilization of Thamnidium elegans fungal culture in environmental cleanup: a reactive dye biosorption study. Ecol Eng 58:363-370. https://doi.org/10.1016/j.ecole ng.2013.06.026

Alencar WS, Lima EC, Royer B, Santos BD, Silva EA, Alves CN, Alencar WS, Lima EC, Royer B, Santos BD (2012) Application of Aqai Stalks as biosorbents for the removal of the dye Procion Blue MX-R from aqueous solution. Sep Sci Technol 47:513-526. https://doi.org/10.1080/01496395.2011.616568

Alves de Lima RO, Bazo AP, Salvadori DMF, Rech CM, de Palma Oliveira D, de Aragão Umbuzeiro G (2007) Mutagenic and carcinogenic potential of a textile azo dye processing plant effluent that impacts a drinking water source. Mutat Res Gen Toxicol Environ 626(1-2):53-60. https://doi.org/10.1016/j.mrgentox.2006.08.002

Baccar R, Sarrà M, Bouzid J, Feki M, Blánquez P (2012) Removal of pharmaceutical compounds by activated carbon prepared from agricultural by-product. Chem Eng J 211-212:310-317. https:// doi.org/10.1016/j.cej.2012.09.099

Bae JS, Freeman HS (2007) Aquatic toxicity evaluation of new direct dyes to the Daphnia magna. Dyes Pigm 73(1):81-85. https://doi. org/10.1016/j.dyepig.2005.10.015
Bazzo A, Adebayo MA, Dias SLP, Lima EC, Vaghetti JCP, de Oliveira ER, Leite AJB, Pavan FA (2016) Avocado seed powder: characterization and its application as biosorbent for crystal violet dye removal from aqueous solutions. Desalin Water Treat 57(34):15873-15888. https://doi.org/10.1080/19443 994.2015.1074621

Calvete T, Lima EC, Cardoso NF, Vaghetti JCP, Dias SLP, Pavan FA (2010) Application of carbon adsorbents prepared from Brazilianpine fruit shell for the removal of reactive orange 16 from aqueous solution: kinetic, equilibrium, and thermodynamic studies. J Environ Manag 91(8):1695-1706. https://doi.org/10.1016/j.jenvm an.2010.03.013

Cardoso NF, Lima EC, Pinto IS, Amavisca CV, Royer B, Pinto RB, Alencar WS, Pereira SFP (2011) Application of cupuassu shell as biosorbent for the removal of textile dyes from aqueous solution. J Environ Manag 92(4):1237-1247. https://doi.org/10.1016/j.jenvm an.2010.12.010

Cardoso NF, Lima EC, Royer B, Bach MV, Dotto GL, Pinto LAA, Calvete T (2012) Comparison of Spirulina platensis microalgae and commercial activated carbon as adsorbents for the removal of Reactive Red 120 dye from aqueous effluents. J Hazard Mater 241-242:146-153. https://doi.org/10.1016/j.jhazmat.2012.09.026

Carneiro PA, Umbuzeiro GA, Oliveira DP, Zanoni MVB (2010) Assessment of water contamination caused by a mutagenic textile effluent/dyehouse effluent bearing disperse dyes. J Hazard Mater 174(1-3):694-699. https://doi.org/10.1016/j.jhazmat.2009.09.106

de Franco MAE, de Carvalho CB, Bonetto MM, Soares RP, Féris LA (2017) Removal of amoxicillin from water by adsorption onto activated carbon in batch process and fixed bed column: kinetics, isotherms, experimental design and breakthrough curves modelling. J Clean Prod 161:947-956. https://doi.org/10.1016/j.jclep ro.2017.05.197

Demarchi CA, Campos M, Rodrigues CA (2013) Adsorption of textile dye Reactive Red 120 by the chitosan-Fe(III)- crosslinked: batch and fixed-bed studies. J Environ Chem Eng 1(4):1350-1358. https ://doi.org/10.1016/j.jece.2013.10.005

Dorado AD, Gamisans X, Valderrama C, Solé M, Lao C (2014) $\mathrm{Cr}(\mathrm{III})$ removal from aqueous solutions: a straightforward model approaching of the adsorption in a fixed-bed column. J Environ Sci Health A 49:179-186. https://doi.org/10.1080/10934 529.2013.838855

dos Reis GS, Adebayo MA, Lima EC, Sampaio CH, Prola LDT (2016) Activated carbons from sewage sludge for preconcentration of copper. Anal Lett 49(4):541-555. https://doi. org/10.1080/00032719.2015.1076833

dos Reis GS, Adebayo MA, Sampaio CH, Lima EC, Thue PS, Dias SLP, de Brum AS, Pavan AF (2017) Removal of phenolic compounds using sludge-based activated carbons prepared by conventional and microwave-assisted pyrolysis. Water Air Soil Pollut 228(33):1-17. https://doi.org/10.1007/s11270-016-3202-7

Dotto GL, Lima EC, Pinto LAA (2012) Biosorption of food dyes onto Spirulina platensis nanoparticles: equilibrium isotherm and thermodynamic analysis. Bioresour Technol 103(1):123-130. https://doi.org/10.1016/j.biortech.2011.10.038

Fidalgo B, Williams HM, Dawson EA, Parkes GMB (2014) Conventional and microwave-heated oxygen pulsing techniques on metal-doped activated carbons. J Porous Mater 21(1):81-89. https://doi.org/10.1007/s10934-013-9750-y

Freundlich HMF (1906) Over the adsorption in solution. J Phys Chem A 57(25):385-471

Guaratini CCI, Zanoni MVB (2000) Corantes têxteis. Quimica Nova 23(1):71-78. https://doi.org/10.1590/S0100-404220000001000 13

Guo H, Li Y, Zhao K, Ren Y, Wei C (2011) Removal of arsenite from water by synthetic siderite: behaviors and mechanisms. J 
Hazard Mater 186(2-3):1847-1854. https://doi.org/10.1016/j. jhazmat.2010.12.078

Gupta VK, Gupta B, Rastogi A, Agarwal S, Nayak A (2011) A comparative investigation on adsorption performances of mesoporous activated carbon prepared from waste rubber tire and activated carbon for a hazardous azo dye-Acid Blue 113. J Hazard Mater 186(1):891-901. https://doi.org/10.1016/j.jhazmat.2010.11.091

Hessel C, Allegre C, Maisseu M, Charbit F, Moulin P (2007) Guidelines and legislation for dye house effluents. J Environ Manag 83(2):171-180. https://doi.org/10.1016/j.jenvman.2006.02.012

Hubbe MA, Beck KR, O'Neal WG, Sharma YC (2012) Cellulosic substrates for removal of pollutants from aqueous systems: a review. 2. Dyes. BioRes 7(2):2592-2687. https://doi. org/10.15376/biores.6.2.2161-2287

Krishni RR, Foo KY, Hameed BH (2014a) Adsorptive removal of methylene blue using the natural-banana leaves. Desalin Water Treat 52(31-33):6104-6112

Krishni RR, Foo KY, Hameed BH (2014b) Adsorption of cationic dye using a low-cost biowaste adsorbent. Desalin Water Treat 52(31-33):6088-6095

Langmuir I (1918) The adsorption of gases on plane surfaces of glass, mica and platinum. J Am Chem Soc 40(9):1361-1403. https://doi. org/10.1021/ja02242a004

Liao P, Yuan S, Xie W, Zhang W, Tong M, Wang K (2013) Adsorption of nitrogen-heterocyclic compounds on bamboo charcoal: kinetics, thermodynamics, and microwave regeneration. J Colloid Interface Sci 390(1):189-195. https://doi.org/10.1016/j. jcis.2012.09.037

Lima EC, Adebayo MA, Machado FM (2015) Kinetic and Equilibrium models of adsorption. In: Bergmann CP, Machado FM (eds) Carbon nanomaterials as adsorbents for environmental and biological applications, 1st edn. Springer, New York, pp 33-69. https://doi. org/10.1007/978-3-319-18875-1_3

Liu Y, Xu H, Yang SF, Tay JH (2003) A general model for biosorption of $\mathrm{Cd}^{2+}, \mathrm{Cu}^{2+}$ and $\mathrm{Zn}^{2+}$ by aerobic granules. J Biotechnol 102(3):233-239. https://doi.org/10.1016/S0168-1656(03)00030-0

Noreen S, Bhatti HN, Nausheen S, Sadaf S, Ashfaq M (2013) Batch and fixed bed adsorption study for the removal of Drimarine Black CL-B dye from aqueous solution using a lignocellulosic waste: a cost affective adsorbent. Ind Crops Prod 50:568-579. https://doi. org/10.1016/j.indcrop.2013.07.065

Patel YN, Patel MP (2013) Adsorption of azo dyes from water by new poly (3-acrylamidopropyl)-trimethylammonium chloride-co- $\mathrm{N}, \mathrm{N}$ dimethylacrylamide superabsorbent hydrogel—equilibrium and kinetic studies. J Environ Chem Eng 1(4):1368-1374. https://doi. org/10.1016/j.jece.2013.09.024

Prola LDT, Machado FM, Bergmann CP, de Souza FE, Gally CR, Lima EC, Adebayo MA, Dias SLP, Calvete T (2013) Adsorption of Direct Blue 53 dye from aqueous solutions by multi-walled carbon nanotubes and activated carbon. J Environ Manag 130:166-175. https://doi.org/10.1016/j.jenvman.2013.09.003
Rathod M, Haldar S, Basha S (2015) Nanocrystalline cellulose for removal of tetracycline hydrochloride from water via biosorption: equilibrium, kinetic and thermodynamic studies. Ecol Eng 84:240-249. https://doi.org/10.1016/j.ecoleng.2015.09.031

Ribas MC, Adebayo MA, Prola LDT, Lima EC, Cataluña R, Feris LA, Puchana-rosero MJ, Machado FM, Pavan FA, Calvete T (2014) Comparison of a homemade cocoa shell activated carbon with commercial activated carbon for the removal of reactive violet 5 dye from aqueous solutions. Chem Eng J 248:315-326. https:// doi.org/10.1016/j.cej.2014.03.054

Rosales E, Meijide J, Tavares T, Pazos M, Sanromán MA (2016) Grapefruit peelings as a promising biosorbent for the removal of leather dyes and hexavalent chromium. Process Saf Environ 101:61-71. https://doi.org/10.1016/j.psep.2016.03.006

Rovani S, Fernandes AN, Prola LDT, Lima EC, Santos WO, Adebayo MA (2014) Removal of Cibacron Brilliant Yellow 3G-P Dye from aqueous solutions by Brazilian peats as biosorbents. Chem Eng Commun 201(11):1431-1458. https://doi.org/10.1080/00986 445.2013.816954

Salame II, Bandosz TJ (1999) Study of water adsorption on activated carbons with different degrees of surface oxidation. J Colloid Interface Sci 210:367-374. https://doi.org/10.1016/S0008 $-6223(03) 00029-0$

Saucier C, Adebayo MA, Lima EC, Prola LDT, Thue PS, Umpierres CS, Puchana-Rosero MJ, Machado FM (2015) Comparison of a homemade Bacury shell activated carbon with carbon nanotubes for food dye removal. CLEAN Soil Air Water 43(10):1389-1400. https://doi.org/10.1002/clen.201400669

SenthilKumar P, Ramalingam S, Senthamarai C, Niranjanaa M, Vijayalakshmi P, Sivanesan S (2010) Adsorption of dye from aqueous solution by cashew nut shell: studies on equilibrium isotherm, kinetics and thermodynamics of interactions. Desalination 261(12):52-60. https://doi.org/10.1016/j.desal.2010.05.032

Sharma M, Vyas RK, Singh K (2013) A review on reactive adsorption for potential environmental applications. Adsorption 19(1):161188. https://doi.org/10.1007/s10450-012-9436-9

Suksabye P, Thiravetyan P (2012) Cr(VI) adsorption from electroplating plating wastewater by chemically modified coir pith. J Environ Manag 102:1-8. https://doi.org/10.1016/j.jenvman.2011.10.020

Sun CL, Wang CS (2010) Estimation on the intramolecular hydrogenbonding energies in proteins and peptides by the analytic potential energy function. J Mol Struct: Theochem 956(1-3):38-43. https ://doi.org/10.1016/j.theochem.2010.06.020

Sun Y, Zhang B, Zheng T, Wang P (2017) Regeneration of activated carbon saturated with chloramphenicol by microwave and ultraviolet irradiation. Chem Eng J 320:264-270. https://doi. org/10.1016/j.cej.2017.03.007

Publisher's Note Springer Nature remains neutral with regard to jurisdictional claims in published maps and institutional affiliations. 